\title{
Formulation and evaluation of novel functional snack bar with amaranth, rolled oat, and unripened banana peel powder
}

\author{
Arshya Singh $^{1} \cdot$ Aparna Kumari $^{1} \cdot$ Anil Kumar Chauhan ${ }^{1}$
}

Revised: 24 November 2021 / Accepted: 3 December 2021/Published online: 18 January 2022

(C) Association of Food Scientists \& Technologists (India) 2021

\begin{abstract}
The present pandemic situation has increased demand for functional foods that enhance all aged groups' people immunity against COVID-19. This factor has led to innovation in snack market because healthy and good quality snack products are lacking. In this study, attempt has been made to develop functional snack bar that is beneficial for malnourished population from various combinations of amaranth grain, oat, and banana peel powder. Among various combinations amaranth grain (60\%), oats $(25 \%)$ and banana peel powder $(15 \%)$ was found better than other combinations in respect to organoleptic and nutritional quality. Oat and banana peel powder addition increased the contents of protein, mineral, $\beta$-glucan, dietary fibre, essential amino acid, phenolic, and antioxidant activity of functional snack bar. TGA analysis shows that active components present in it were stable even at high temperature which adds benefit to its functional property. Microbial studies of FSB revealed it could be stored up to 60 days without microbial contamination and acceptable by consumer. The cost of a functional snack bar was 9.57 per bar, which was less than market snack bar. This study showed that developed functional snack bar snack increases market's revenue and enables snack market to develop new type snack bar.
\end{abstract}

Anil Kumar Chauhan

anilchauhancfst@gmail.com

Arshya Singh

arshyasingh22@gmail.com

Aparna Kumari

arpita1.1997@gmail.com

1 Department of Dairy Science and Food Technology, Institute of Agricultural Science, Banaras Hindu University, Varanasi, Uttar Pradesh 221005, India
Keywords Amaranth · Oat - Banana peel powder - Amino acid $\cdot$ Antioxidant activity

\section{Introduction}

In the present pandemic situation, consumers prefer functional food that is beneficial for the body and contributes to a healthy lifestyle, and at the same time, they are also convenient for storage, handling and consumption. World Health Organization (2004) also promotes the preparation of innovative food products that symbolize nutritious and healthy choices for consumers. In this sense, ready-to-eat products, such as snack bars, are the most appropriate option for consumers' healthy lifestyles (Sloan 2005). With an increase in health awareness and increased per capita expenses on quality food, India's snack bar sector is projected to evolve at a phenomenal speed. According to the market survey, the snack bar's demand in the Indian market to grow at a compound annual growth rate (CAGR) of around $25 \%$ is predicted to be in the fore coming years (2020-2025). Rising fitness consciousness, healthy behaviors, and awareness of the benefits of eating smaller meals contribute to increased snack intake, which is expected to fuel demand for snack bars (Pinto et al. 2017). Conventionally, Indian families would cook snacks at home for consumption during meals or during travel. However, with a rise in urban population, increased per capita income, more active lifestyles, higher disposable incomes, and a necessity for convenience emerging from fast-paced lifestyles, demand for ready-to-eat snacks has increased.

Amaranth grain (Amaranthus cruentus) is a pseudo-cereal consumed worldwide, possesses many nutritional benefits, and is consumed as a potential dietary supplement (Pavlik 2012). Amaranth grains are excellent source of 
protein, essential minerals such as calcium phosphorus, and iron (Correa et al. 1986). Amino acid is a building block of the body present in a minimal amount in cereals grains, but amaranth grain has a relatively higher content of essential amino acids such as tryptophan and lysine than other cereals. So, lysine and tryptophan content in amaranth can compete with any animal proteins (Písaříková et al. 2005). It can be used to treat malnourished children and older people. It is also a gluten-free cereal, and therefore, it is a good source of nutrition for celiac disease. It is often popped up and used to make confectionery products such as laddoos and chikkis (Mogarkar and Morable 2018). Amaranth grains manifest antioxidant activity related to their content of tocopherols, polyphenols, flavonoids, and anthocyanins (Escudero et al. 2011). Antioxidants can serve a significant role in inhibiting oxidative chain reactions and free radicals in tissues and membranes that protects the body from tissue damage.

Banana (Musa sapientum) is a prevalent fruit in India and other parts of the world due to its high nutritional content and low price. The skin or peel is about $350 \mathrm{~g} \mathrm{~kg}^{-1}$ of the total mass of fresh ripe banana fruit and is generally considered waste products and thrown away or used in compost to make manure for plants (Carvalho and ContiSilva 2018). Due to continuous development in the food market in recent decades, researchers and food technologists are investigating the feasibility of using banana peels for human nutrition and have found that banana peels provide significant health benefits. The banana peel is rich in protein, dietary fibre, polyunsaturated fatty acids, essential amino acids, and potassium, as well as it contains antioxidants and polyphenols that help combat many chronic diseases such as cancer, cardiovascular diseases, cataract, and age-related functional decline (Puraikalan 2018).

Oats (Avena sativa) has gained much popularity due to their high nutritional value, dietary fiber, and phytochemicals. It is a well-known fact that the consumption of oat on daily basis possesses numerous health benefits such as hypo-cholesterolaemic and has anti-cancerous properties due to the presence of $\beta$-glucan (a soluble fiber) (Rasane et al. 2015). In 2013, the FDA also approved a health advisory on the consumption of oatmeal, oat bran, or oat flour to lowered coronary heart disease. USFDA in 1997, approved the health claim stating that $3 \mathrm{~g} /$ day of oat that contains $\beta$-glucan may help decline lower-density lipoprotein (LDL-C) level.

Sugar causes many dental problems and diabetes, so sugar can be replaced with jaggery because it has long sucrose chains that are digested slowly and can provide energy to the body for a longer time (Nath et al. 2015). It also is an abundant source of essential minerals such as $\mathrm{Fe}$, $\mathrm{Mg}, \mathrm{Ca}, \mathrm{K}, \mathrm{P}, \mathrm{Na}$ and a good source of vitamins such as retinol, thiamine, riboflavin, pantothenic acid, pyridoxine, Vitamin C, Vitamin D, tocopherol, and protein (Sahu and Paul 1998).

Following market research and industry dynamics, this study aims to formulate a functional snack bar with amaranth grain, banana peel, oats, and jaggery for customers at a very nominal price, and its physiochemical, sensory, and bioactive properties were evaluated.

\section{Materials and methods}

\section{Materials}

The raw materials such as amaranth grains, rolled oat flakes, jaggery was procured from the local market of Varanasi, India. All the chemicals used in the study were of analytical grade.

\section{Methods for preparation of raw material}

Raw amaranth grains were popped by hot air using fluidised bed systems in which hot air moving at $1.6 \mathrm{~m} / \mathrm{s}$ velocity and amaranth grains were fed in at another point, lifted and popped by the heat at $120^{\circ} \mathrm{C}$ for $36 \mathrm{~s}$. The rolled oats were roasted in the frying pan at $120^{\circ} \mathrm{C}$ to $150{ }^{\circ} \mathrm{C}$ temperature. The banana peel powder was prepared by slicing the peel into 2 inches, blanched, and then dried in a tray drier (Khera Instruments Pvt. Ltd.) at $50-55^{\circ} \mathrm{C}$ at an air velocity of $2.5 \mathrm{~m} / \mathrm{s}$ for minimum loss of nutrients. The dried banana peel was passed through the high-speed grinder (Bosch Pro grinder) and sieved to a size of $100 \mu \mathrm{m}$ to produce the fine banana peel powder.

\section{Formulation of functional snack bar}

Four variants of the FSB were prepared by combining different proportions of the popped amaranth grain, oats and banana peel powder which was further formulated on the basis of sensory assessment. Table 1 depicts the experimental design of the variations for the preparation of functional and controls snack bars. The banana peel

Table 1 Different level of amaranth, oat and banana peel powder for standardization of functional snack bar

\begin{tabular}{lllllll}
\hline Ingredients (\%) & \multicolumn{7}{l}{ Variations } \\
\cline { 2 - 7 } & Control & $\mathrm{F}_{1}$ & $\mathrm{~F}_{2}$ & $\mathrm{~F}_{3}$ & $\mathrm{~F}_{4}$ & $\mathrm{~F}_{5}$ \\
\hline Amaranth grain & 90 & 80 & 70 & 60 & 50 & 40 \\
Oats & 10 & 15 & 20 & 25 & 30 & 35 \\
Banana peel powder & 0 & 5 & 10 & 15 & 20 & 25 \\
\hline
\end{tabular}


powder substitution level was not more than $25 \%$ because of the astringent nature of banana peel that could result in an undesirable bitter taste in the snack bar. These substitutions also ensured that banana peel powder could meet the daily requirement for dietary fibre for adolescents and children. Amaranth and oat composite was prepared in ratio that provided protein, carbohydrate and energy which help to combat malnutrition.

\section{Preparation of the functional snack bar}

The functional snack bar (FSB) was prepared using popped amaranth grains, oats, banana peel powder and jaggery, as depicted in Fig. 1a and b while control bar was prepared by using only popped amaranth grains and jaggery syrup.

\section{Formulation of FSB by sensory analysis}

The formulation of the level of amaranth grain, banana peel powder, oat flakes, and jaggery for the preparation of functional snack bar was based on sensory analysis according to the procedure explained by Momanyi et al. (2020) on a 9-point hedonic scale. The mean sensory score of 12 semi-trained judges for each quality parameter viz., colour, appearance, texture (crispiness and graininess), aroma, taste and overall acceptability was recorded.

\section{Determination of proximate composition and mineral elements}

The proximate composition (moisture, crude fat, crude protein, and total ash) were determined by AOAC (2019) methods. The total carbohydrates were determined by the (a)

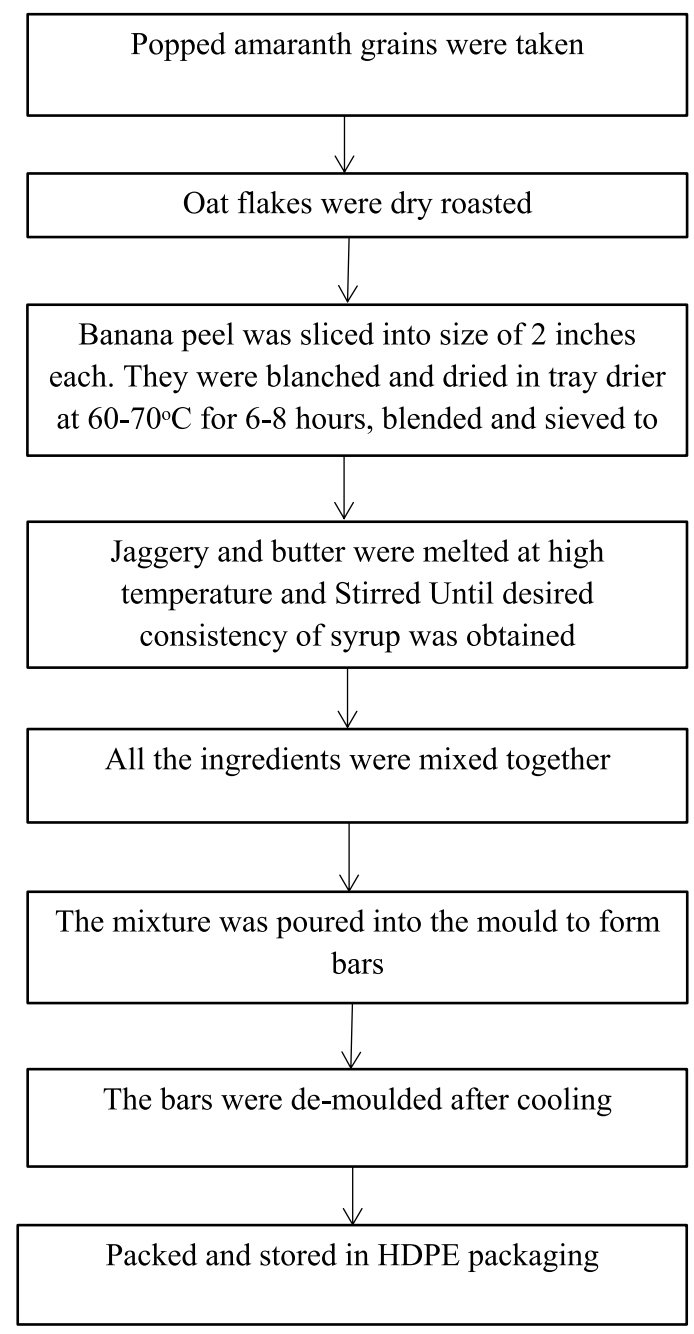

(b)

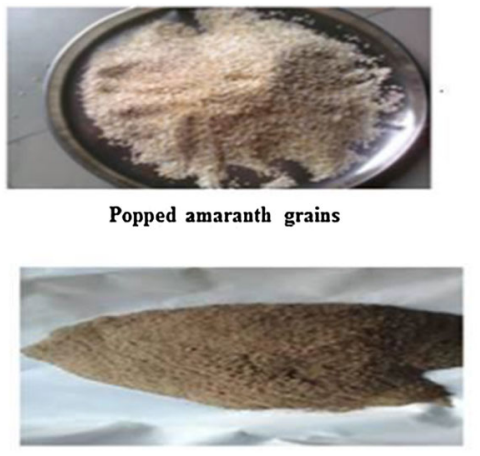

Jaggery syrup

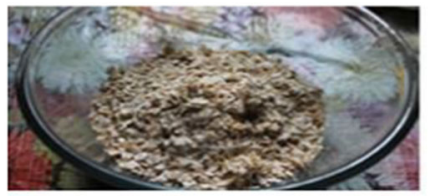

Roasted rolled oats

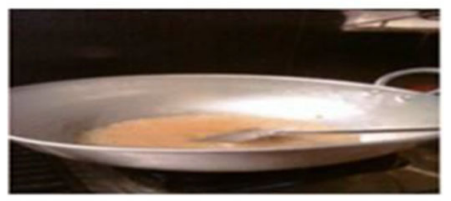

Banana peel powder

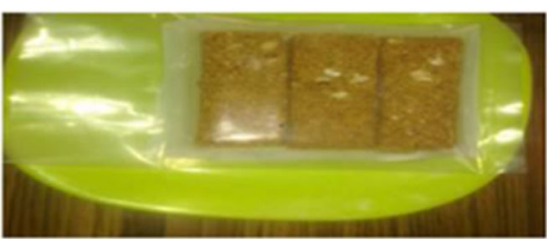

Functional snack bar

Fig. 1 a Flowchart for the formulation of functional snack bar (FSB). b Diagrammatic representation of formulation of functional snack bar (FSB) 
difference method. The total dietary fibre of FSB was determined by using AOAC Method No. 991. Mineral elements like iron $(\mathrm{Fe})$, phosphorus $(\mathrm{P})$ and calcium $(\mathrm{Ca})$ were detected by using flame atomic absorption spectroscopy (Shimadzu, Japan).

\section{$\beta$-glucan estimation of functional snack bar}

$\beta$-glucan was estimated by the enzymatic method mentioned by Flander et al. (2007) using the Megazyme International assay kit. The average molecular weight of the $\beta$-glucan in the sample was analyzed by stirring $1 \mathrm{~g}$ of the sample for $12 \mathrm{~h}$ in a magnetic stirrer with $1 \mathrm{~L}$ of $0.1 \mathrm{~N}$ $\mathrm{NaOH}$ containing $1 \% \mathrm{NaBH}_{4}$. The samples were analyzed in the HPLC-SEC using calcofluor white stain (Sigma).

\section{Colour and texture}

Consumer acceptability is significantly influenced by the colour and texture of snack bars. HunterLab ColorFlex EZ, was used for determining the color values in terms of $\mathrm{L}^{*}$ $(100=$ white $; 0=$ black $), \quad a^{*} \quad($ positive $=$ red; negative $=$ green $)$, and $\mathrm{b}^{*}($ positive $=$ yellow; negative $=$ blue $)$. The FSB was crushed; filled $3 / 4$ into the measuring head, and the colour value was detemined.

The texture of the FSB was determined using a texture analyzer (TA-TX2 plus, M/s Stable Micro Systems Ltd, Godalming, Surrey, England)) with a $10 \mathrm{~kg}$ load cell. A vertical force was applied to the snack diameter at a crosshead test speed of $8.33 \mathrm{~mm} / \mathrm{s}$ and distance of $0.50 \mathrm{~mm}$. The results were stated in terms of the mean from 7 replicates of each snack bar sample.

\section{Nutraceutical characteristics of functional snack bar}

\section{Total phenolics content}

Total phenol content was determined with Folin-Ciocalteu reagent (FCR) by procedure of Huang et al. (2005) with slight modification in which $500 \mu \mathrm{g}$ of the sample was mixed to $2.5 \mathrm{ml}$ of $0.2 \mathrm{~N} \mathrm{FCR}$ and placed for $15 \mathrm{~min}$ in dark, then $1 \mathrm{ml}$ of $75 \mathrm{~g} / \mathrm{l}$ of $\mathrm{Na}_{2} \mathrm{CO}_{3}$ was added to it. The above mixture was incubated for $2 \mathrm{~h}$ at room temperature and the absorbance was measured at $760 \mathrm{~nm}$. The total phenol content of the formulated bar was calculated from the regression equation of the standard gallic acid curve $\left(y=1.8728 x+0.1629 R^{2}=0.9982\right)$, and the result was stated in term of $\mathrm{mg} \mathrm{GAE} / \mathrm{g}$.

\section{Antioxidant assays}

The antioxidant activity of the formulated snack bar is done using two methods:
DPPH (2, 2-diphenyl-1-picrylhydrazyl) assay Free radical scavenging activity was measured by the method reported by Chanda and Dave (2009) using stable DPPH. The results were expressed as percent inhibition using the formula.

DPPH inhibition percentage $(\% I)=$ A $0-$ AS $/ \mathrm{A} 0 \times 100$

where A0 is the absorbance of the control, AS is the absorbance in the presence of the sample.

FRAP (ferric ion reducing antioxidant power) assay The FRAP method was adopted to estimate the antioxidants according to the protocol mentioned by Tyagi et al. (2020). Ferrous sulfate $(\mathrm{Fe})$ was used as standard, and results were expressed as $\mu \mathrm{mol} \mathrm{Fe}(\mathrm{II}) / 100 \mathrm{~g}$ of dry matter.

\section{Determination of amino acids}

The amino acid of the functional snack bar was estimated using thin-layer chromatography (TLC) using silica gel GF60 of analytical grade and using ninhydrin as a detection reagent according to the procedure mentioned by Darmasiw et al. (2018). The samples were prepared in triplicates in $10 \mathrm{ml}$ solvents (ethanol, hexane, distilled water). Samples were after that spotted in the TLC plates using microcapillary tubes. They were then air-dried for a few minutes before being subjected to the mobile phase n-butanol: acetic acid: water (3:1:1). After the mobile phase run-up over the TLC plates, the samples were dried and dipped in ninhydrin reagents, followed by warm-hearted plates for a few minutes.

\section{Thermogravimetric analysis (TGA)}

The TGA investigation was conveyed by TGA-4000 Perkin Elmer (CURIE GRANT). The standard protocol was followed for analysis in which sample were grounded into powder and sieved. In each test about $5 \mathrm{mg}$ of sample was used. Samples were taken in a crucible and after tarring the weight of crucible were kept in assembly and software was made to run. The temperature range was from $25^{\circ} \mathrm{C}$ to $900{ }^{\circ} \mathrm{C}$. Loss in weight (Weight \%) was observed against temperature $\left({ }^{\circ} \mathrm{C}\right)$, and from the Pyris software, graphs were achieved for each sample (Tyagi et al. 2020).

\section{Microbial analysis}

All the samples were subjected to microbiological analysis for total plate count (TPC), yeast and mold count (YMC) and coliform count. Total plate count was estimated using plate count agar (PCA, HiMedia, Mumbai, India), whereas yeasts and molds were estimated using the potato dextrose agar (PDA, HiMedia, Mumbai, India). Coliforms count 
was determined using violet red bile agar (VRBR, HiMiedia, Mumbai, India) after incubation at $37^{\circ} \mathrm{C}$ for $48 \mathrm{~h}$. The FSB and control were tested for their shelf stability after 60 days.

\section{Statistical analysis}

All the experiments were carried out in triplicate, and the results were expressed as mean $\pm \mathrm{SD}$ (Standard deviation). Statistical analysis was performed using one way ANOVA in MINITAB 17 Software.

\section{Cost estimation}

The cost estimation of the formulated product was done to compare it with the options available in the market.

\section{Results and discussions}

\section{Selection of best formulations}

Formulation of the functional snack bar (FSB) was based on sensory assessments. Table 2 shows the data of the sensory evaluation of the FSB with different levels of oat and banana peel powder that was formulated by one way ANOVA (MINITAB 17). It was observed that increasing the concentration of banana peel powder gradually decreasing the acceptability in all sensory parameters such as aroma, taste, texture, colour and appearance of FSB. So the formulation of a snack bar with a low level of banana peel powder was most preferred. At $20 \%$ and $25 \%$, levels of banana peel powder in FSB showed a significant unacceptable change in all sensory properties because banana peel powder was astringent in nature. It means that the increasing BPP in the FSB bars beyond $20 \%$ and 25\% levels decreased the liking. Sensory data at $15 \%$ of BPP was significantly different against control but not significant with 5\% and 10\%, were in an acceptable range and create good impression of a quality product. So, it can be concluded that $15 \%$ of the banana peel powder was acceptable in all sensory attributes. Hence, FSB with $60 \%$ of amaranth grain, $15 \%$ of the banana peel powder, and $25 \%$ oats content was acceptable in all sensory attributes without causing any adverse effect and was considered an optimized functional snack bar. Momanyi et al. (2020) also observed a similar trend in baobab based ready-to-eat sorghum and cowpea blend snack bars, where when the concentration of baobab (0-20\%) was increased, decreased in sensory scores are given by the panellists.

\section{Proximate composition of functional energy bar}

The proximate analysis result of the functional snack bars is shown in Table 3. There were no significant differences observed in the moisture content of the control and functional snack bar. Its values ranged from $11.21 \%$ to $10.56 \%$ respectively. After popping of amaranth grain and roasting of oat flakes, the moisture content from the final product was reduced. Low moisture content indicates that the snack bar is microbiologically safe and has more shelf-life. Low moisture content also gives the functional snack bar a low bulk density and a crunchy texture. Crude protein of CSB and FSB ranged between 9.62 and 12.07 per cent, respectively. Compositing amaranth grain, oat flakes, and banana peel powder improve protein quality in functional snack bar. Increased protein content can address issues of proteinenergy malnutrition. The ash content represents minerals present in a food. The ash content of the snack bar ranged from $3 \%$ in the control sample to $4.07 \%$ in the functional snack bar. It was observed that the ash content of the samples increased with the addition of oat and banana peel powder. The crude fat content in the control and functional snacks bar was 2.02 and $2.18 \%$, respectively. These fat values indicate that fat content was non-significant. The energy value for the FSB and the control was $332.78 \pm 0.88$ and $316.14 \pm 0.64 \mathrm{kcal}$, respectively. It can be conclude from proximate result of FSB that two times serving of FSB are able to meet the total RDI among children, adolescent girls and boys women. The results regarding the increase in proximate composition of FSB are similar to the findings of Ramírez-Jiménez et al. (2018),
Table 2 Sensory acceptability of control snack bar (CSB) and functional snack bar (FSB)

\begin{tabular}{lllll}
\hline Variants & Colour and Appearance & Aroma and taste & Body and texture & Overall acceptability \\
\hline Control & $8.40 \pm 0.56$ & $7.90 \pm 0.55$ & $8.00 \pm 0.42$ & $8.30 \pm 0.88$ \\
$\mathrm{~F}_{1}$ & $8.32 \pm 0.33$ & $7.90 \pm 0.88$ & $8.62 \pm 0.8$ & $8.50 \pm 0.56$ \\
$\mathrm{~F}_{2}$ & $8.25 \pm 0.17$ & $7.83 \pm 0.56$ & $8.4 \pm 0.78$ & $8.02 \pm 0.63$ \\
$\mathrm{~F}_{3}$ & $8.09 \pm 0.33^{*}$ & $7.60 \pm 0.11^{* *}$ & $8.20 \pm 0.63^{*}$ & $7.85 \pm 0.66$ \\
$\mathrm{~F}_{4}$ & $6.50 \pm 0.88$ & $6.31 \pm 0.85$ & $8.03 \pm 0.58$ & $6.55 \pm 0.83$ \\
$\mathrm{~F}_{5}$ & $6.40 \pm 0.84$ & $6.15 \pm 0.75$ & $7.92 \pm 0.42$ & $6.00 \pm 0.90$ \\
\hline
\end{tabular}

Values are Mean \pm Standard deviation $(\mathrm{SD})$ of triplicates $(* p<0.05 ; * * p<0.01 ; * * * p<0.001$; CSB compared with FSB) 
Table 3 Proximate Composition and trace minerals of the FSB and CSB

\begin{tabular}{|c|c|c|}
\hline Constituents & Amounts (\%) for control & Amounts (\%) for FSB \\
\hline Moisture & $11.21 \pm 0.55$ & $10.56 \pm 0.42$ \\
\hline Fat & $2.02 \pm 0.21$ & $2.18 \pm 0.44$ \\
\hline Protein & $9.62 \pm 0.76$ & $12.07 \pm 0.35^{* *}$ \\
\hline Ash & $3.00 \pm 0.02$ & $4.07 \pm 0.05^{*}$ \\
\hline Dietary Fibre & $5.12 \pm 0.74$ & $9.06 \pm 0.23 * * *$ \\
\hline Carbohydrate & $69.03 \pm 0.88$ & $62.06 \pm 0.24$ \\
\hline Energy(kcal) & $332.78 \pm 0.64$ & $316.14 \pm 0.88$ \\
\hline Iron $(\mathrm{mg}) / 100 \mathrm{~g}$ & $8.32 \pm 0.11$ & $11.17 \pm 0.32 *$ \\
\hline Phosphorus (mg)/100 g & $122.12 \pm 0.25$ & $268.77 \pm 0.52 * *$ \\
\hline Calcium (mg)/100 g & $172.58 \pm 0.62$ & $226.89 \pm 0.46^{* *}$ \\
\hline$\beta$-glucan(per $100 \mathrm{~g}$ ) & - & $1.5 \pm 0.18$ \\
\hline \multicolumn{3}{|l|}{ Colour } \\
\hline $\mathrm{L}^{*}$ & $36.82 \pm 0.02$ & $34.97 \pm 0.02 * *$ \\
\hline$a^{*}$ & $3.25 \pm 0.04$ & $3.62 \pm 0.03^{*}$ \\
\hline$b^{*}$ & $5.88 \pm 0.02$ & $5.53 \pm 0.01$ \\
\hline \multicolumn{3}{|l|}{ Texture } \\
\hline Hardness (kg) & $7.456 \pm 0.05$ & $7.715 \pm 0.22$ \\
\hline Fracturability (s) & $5.716 \pm 0.55$ & $5.778 \pm 0.62$ \\
\hline TPC (mgGAE/g) & $152.04 \pm 0.68$ & $190.34 \pm 0.97 * *$ \\
\hline$\%$ DPPH inhibition & $36.26 \pm 0.23$ & $48.50 \pm 0.32 *$ \\
\hline FRAP $\mu \mathrm{mol} \mathrm{Fe}(\mathrm{II}) / 100 \mathrm{~g}$ of dry matter & $2256.33 \pm 0.49$ & $3011.56 \pm 0.96 * *$ \\
\hline
\end{tabular}

Values are Mean \pm Standard deviation $(\mathrm{SD})$ of triplicates $(* p<0.05 ; * * p<0.01 ; * * * p<0.001$; CSB compared with FSB) who observed that the addition of legumes in the snack bar protein, ash content were significantly increased.

\section{Total dietary fibre}

The total dietary fibre content of the FSB was found to be $9.06 \mathrm{~g} / 100 \mathrm{~g}$, whereas dietary fibre content in the CSB was found to be $5.12 \mathrm{~g} / 100 \mathrm{~g}$, as shown in Table 3. The total dietary fibre content in the FSB was more as compared to the control bar due to banana peel powder and oat, as it is an abundant reserve of dietary fibre. Individuals with higher dietary fibre consumption daily tend to be at substantially reduced risk of experiencing diseases such as gastrointestinal disorders, lowers serum cholesterol levels, reduces the risk of stroke, asthma, diabetes, obesity and blood pressure. Increased consumption of soluble fibre increases glycemia and insulin sensitivity in non-diabetic and diabetic persons. Also, dietary fibre consumption promotes weight loss in individuals. According to a study by Puraikalan (2018), banana peel contained 14\% fibre; this coincides with the fact that banana peel was a major contributor to the total dietary fibre content in the FSB.

\section{Mineral content in functional snack bar}

Table 3 shows the mineral composition of the control and functional snack bar. The iron content was $11.17 \mathrm{mg}$ in the functional snack bar, while in the control snack bar; iron content was $8.32 \mathrm{mg} / 100 \mathrm{~g}$. Iron help to combat in iron deficiency anemia which is global health problem for developed and developing countries (Kumari and Chauhan 2021). The increased iron content in FSB was due to jaggery, oats, and banana peel powder, which was not present in the control bar. The mineral content of FSB meets the FDA standard that classified that iron-rich bar should give at least 5-35 mg of iron per day. Thus, FSB can be consumed by pregnant women and malnourished children of age group 6-16 years of age. The phosphorus content in the formulated snack bar and control bar was 268.77 and $122.12 \mathrm{mg}$. The calcium content in the formulated snack bar and control bar was $226.89 \mathrm{mg}$ and $172.58 \mathrm{mg}$. These results correlated with Munhoz et al. (2014) findings that observed a gradual increase in mineral content with increasing concentration of bocaiuva in the cereal snack bar. 


\section{$\beta$-glucan in functional snack bar}

$\beta$-glucan possesses a hypocholesterolemic effect and is known to reduce blood glucose levels. In the stomach, oatsoluble fiber $\beta$-glucan acts primarily by increasing the viscosity within the gastric and intestinal tract, and the action is mediated via the neurohormonal systems involving both endocrinal and gastrointestinal hormones (Joyce et al. 2019). Oat flakes containing functional snack bars had significantly higher $\beta$-glucan $(1.5 \mathrm{~g} / 100 \mathrm{~g})$ than control snack bars, as presented in Table 3. The amount of $\beta$ glucan was negligible in the control snack bar as the content of oats was in the very less amount. Flander et al. (2007) developed a bread containing oats that had $\beta$-glucan content of around $1.3 / 100 \mathrm{~g}$. As per this study, the functional energy bar has more amount of $\beta$-glucan content.

\section{Colour and texture}

The result of the color and texture analysis of CSB and FSB are presented in Table 3. Hunter $\mathrm{L}^{*}, \mathrm{a}^{*}$, and $\mathrm{b}^{*}$ values of the control snack bar were found to be $36.82 \pm 0.02$, $3.25 \pm 0.04$, and $5.88 \pm 0.02$, respectively. Addition of banana peel to the snack bar brightness values $\left(\mathrm{L}^{*}\right)$ and the yellowness $\left(b^{*}\right)$ was slightly decreased, and the redness $\left(a^{*}\right)$ increased when compared to the control sample. The dark spot in the snack bars has been linked with the amaranth-oat composite. Oats have good amino acid content with remarkably high proportions of lysine. During roasting or baking, proteins undergo Maillard browning reaction characterized by a dark color in the snack bars. Thus via hunter colour lab equipment, the colour of FSB was found to be yellow-brown. The result conforms with Puraikalan (2018), who reported the decrease in color ( $\mathrm{L}^{*}$ and $\mathrm{a}^{*}$ value) of the extruded product (pasta) with an increase in the content of banana peel powder.

The textural quality has affected due to addition of banana peel powder. It was observed that the hardness and fracturability of the snack bar increased upon the addition of banana peel powder. The hardness and fracturability of control candy are $7.456 \pm 0.22 \mathrm{~g} \mathrm{~s}$ and $5.716 \pm 0.55 \mathrm{~s}$, respectively, which are increased to $7.715 \pm 0.05 \mathrm{~g} \mathrm{~s}$ and $5.778 \pm 0.55 \mathrm{~s}$ in formulated functional snack bar. The hardness of the FSB was increased due to the high fiber content in the banana peel powder. Mridula et al. (2011) also found a similar result in omega- 3 rich energy bars using flaxseeds; the hardness increased by the amount of flaxseeds.

\section{Amino acid estimation}

Analysis of essential amino acids using TLC plates and ninhydrin as detector shows that essential amino acids (lysine, leucine, isoleucine, and valine) spot were formed more distinct in the functional snack bar. In contrast, in the control snack bar, no clear spot of essential amino acids were detected. The Amino acids appeared to be pink to brown and can be seen in the TLC plate via visual observation (Fig. 2). The amino acid was present in FSB because of the presence of oat. These amino acids protecting the digestive system, and their deficiency hinder the healing recovery process. This result followed the results reported by Elgubbi and Miltan (2015), where the amino acids were measured using TLC and Ninhydrin Reagent.

\section{Nutraceutical characteristics}

\section{Antioxidant activity}

The values depicted in Table 3 of antioxidant activity in term of DPPH and FRAP of FSB was found to be $48.50 \%$ and $3011.56 \mu \mathrm{mol} \mathrm{Fe}(\mathrm{II}) / 100 \mathrm{~g}$ of dry matter respectively. When the result of CC and FC were compared with each other, increased antioxidant values of FSB because banana peel powder, oats together have a good free radical scavenging property and exhibits good antioxidant property (Dahri et al. 2017). We can say that banana peel and oats is significantly affecting the radical scavenging activity of the functional snack bar. Identical results for DPPH values were also reported by Oguntoyinbo et al. (2021) that the antioxidant power of cookies incorporated with banana peel powder was higher than the control cookies.

\section{Total phenolic content}

Table 3 shows the total phenolic content (TPC) of CSB and FSB. Phenolic compounds are natural antioxidants that have many health benefits and improve the oxidative

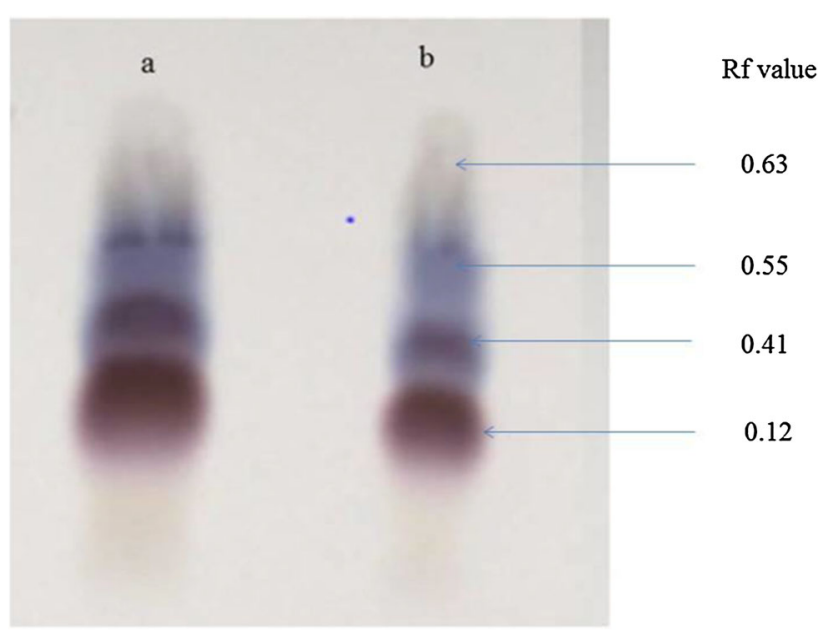

Fig. 2 a Amino acids of the functional snack bar on a TLC plate. b Amino acids of control snack bar on a TLC plate 
(a)

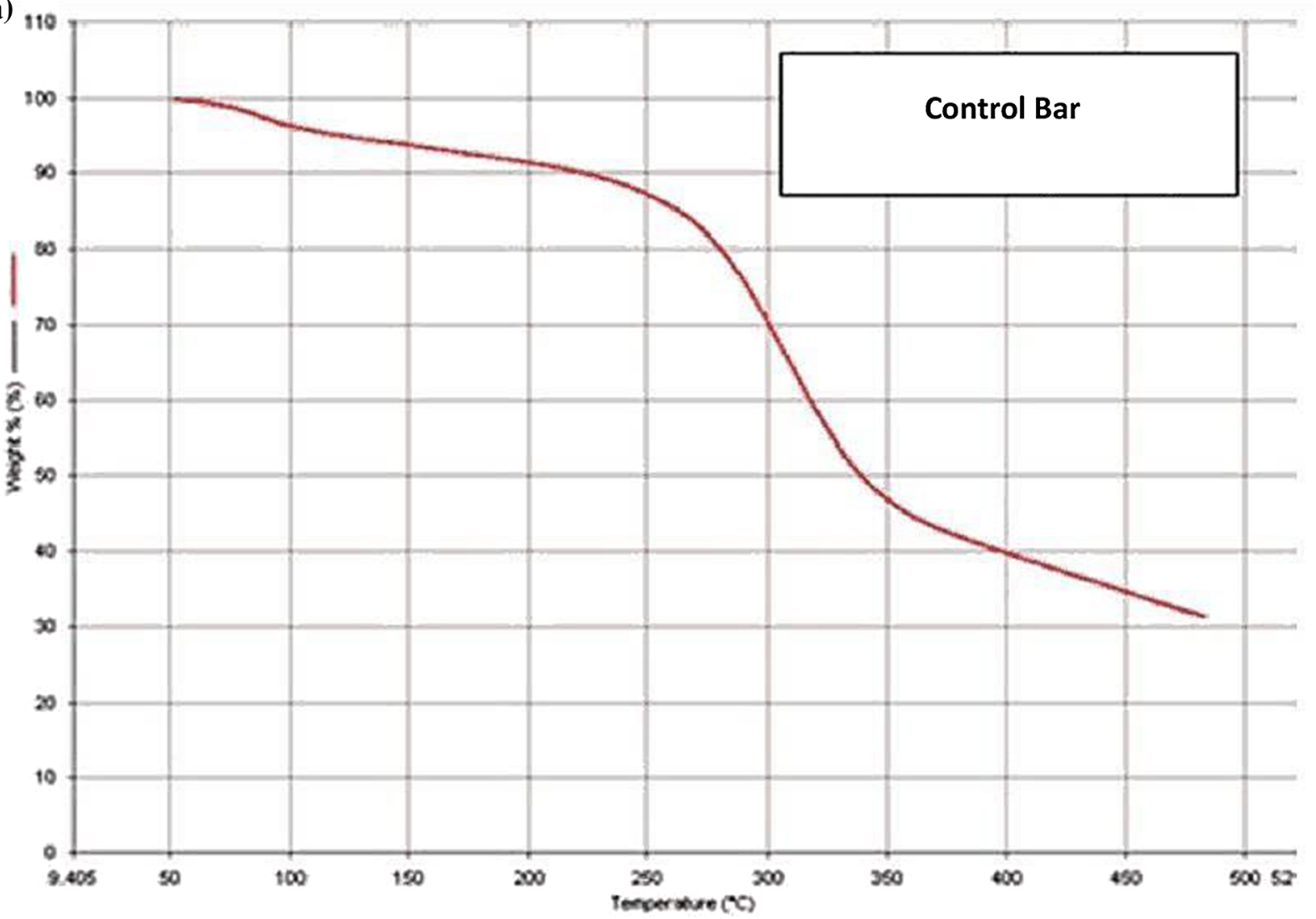

(b)

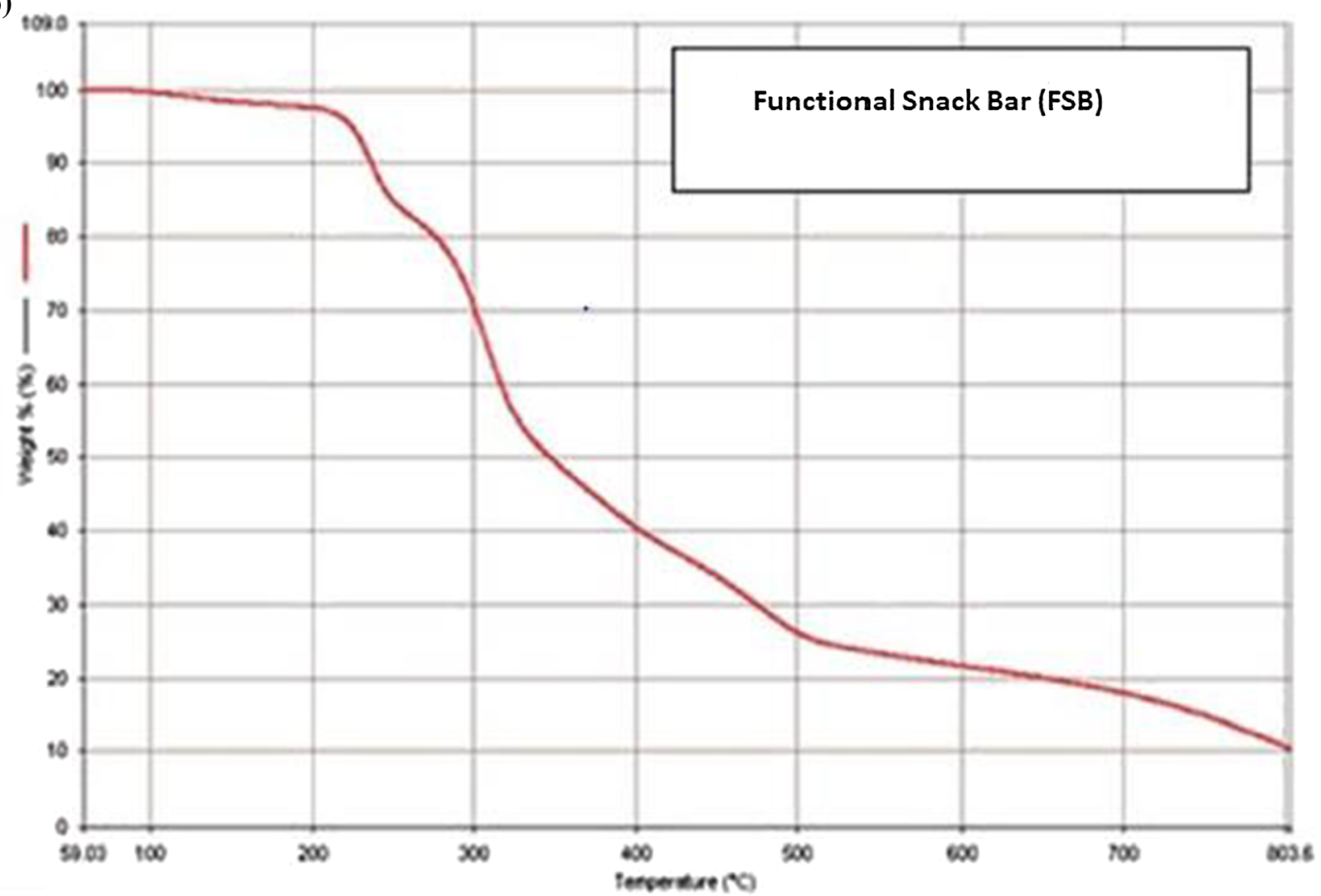


4Fig. 3 a TGA Curve for control snack bar. b TGA Curve for functional snack bar

stability of foods (Devi et al., 2016). Plant-based food products are rich sources of polyphenols and flavonoids having antioxidant and nutraceutical properties. Total Phenolic content in FSB was $190.34 \mathrm{mg}$ GAE/g which was significantly $(p<0.05)$ higher than the control snack bar (152.04 mgGAE/g). Increased total phenolic content in FSB correlates to the fact that the presence of oats and banana peel powder increased the total phenolic content of food products (Dahri et al. 2017).

\section{Thermogravimetric analysis (TGA)}

Figure $3 \mathrm{a}$ and $\mathrm{b}$ shows the TGA curve of the amaranth grain and FSB, respectively. TGA investigation of amaranth grain shows that weight loss started at a very initial stage at temperature $87{ }^{\circ} \mathrm{C}$ and $96 \%$ weight of amaranth grain. The second weight loss at $88 \%$ of amaranth grain weight and phase transition of amaranth grain was noticed at $255^{\circ} \mathrm{C}$ temperature. TGA curve clearly shows that the active compound of amaranth grain can be withstand and stable up to a temperature of more than $250{ }^{\circ} \mathrm{C}$, and from the FSB curve, when amaranth grain is mixed with the formula of the snack bar, initial weight loss temperature increased and stability of the active compound in snack bar slightly decreased. So, final temperature of the melting point of of FSB and amaranth grain was observed at $223{ }^{\circ} \mathrm{C}$ and $255^{\circ} \mathrm{C}$, respectively. Therefore, investigation proved that amaranth grain to be stable, without any loss of its bioactive compound, and withstand during pooping temperature of functional snack bar. Bet et al. (2018) also reported thermal decomposition character of amaranth flour and concluded that the defatted sample, a stability period was found up to $226^{\circ} \mathrm{C}$.

\section{Microbial analysis}

TPC, coliform, yeast, and mold count is the simplest test for the safety of food from a microbiological stand point. The result of total plate count, coliform count and yeast and mold count of functional and control snack bar are shown in Table 4. The result shows that FC has lesser total plate and coliform count than the control candy because of the presence of banana peel powder in FSB, whereas yeast and mold count was nil for both. Previous research confirms that banana peel powder has antimicrobial activity against E Coli, S. aureus, and Proteus mirabilis due to the bioactive compound tannins, flavonoids, alkaloids, terpenoids, phlobatannins, and glycosides (Kapadia et al. 2015). The data obtained from the microbial analysis

Table 4 Comparative values for microbial analysis content of FSB after 60 days

\begin{tabular}{|c|c|c|c|c|c|c|}
\hline \multirow[t]{2}{*}{ Storage time (in days) } & \multicolumn{2}{|c|}{ Total plate count $(\mathrm{cfu} / \mathrm{g})$} & \multicolumn{2}{|c|}{ Coliform count $(\mathrm{cfu} / \mathrm{g})$} & \multicolumn{2}{|c|}{ Yeast and mold count $(\mathrm{cfu} / \mathrm{g})$} \\
\hline & $\mathrm{CC}$ & FC & $\mathrm{CC}$ & FC & $\mathrm{CC}$ & $\mathrm{FC}$ \\
\hline 0 & $x$ & $x$ & $x$ & $x$ & $x$ & $x$ \\
\hline 30 & $1.2 \times 10^{2}$ & $1 \times 10^{2}$ & $3.4 \times 10^{2}$ & $3.0 \times 10^{2}$ & $\times$ & $\times$ \\
\hline \multirow[t]{2}{*}{60} & $1.4 \times 10^{2}$ & $1.3 \times 10^{2}$ & & & & \\
\hline & $3.9 \times 10^{2}$ & $3.5 \times 10^{2}$ & $x$ & $x$ & & \\
\hline
\end{tabular}

$* x=$ not visible growth

Table 5 Cost estimation of the functional snack bar

\begin{tabular}{llll}
\hline Ingredients & Quantity (per/kg) & Rate (Rs./kg) & Total cost (Rs./kg) \\
\hline Popped Amaranth grains & 200 & 105 & 21 \\
Oats & 180 & 195 & 35.1 \\
Banana peel powder & 120 & 0 & 0 \\
Jaggery & 340 & 40 & 13.60 \\
Butter & 60 & 400 & 24 \\
Water & 100 & $20 / \mathrm{L}$ & 2.00 \\
Total & 1000 & & 95.7 \\
Per $100 \mathrm{~g}$ & 100 & & 9.57 \\
\hline
\end{tabular}


showed that the candy was shelf-stable for up to 60 days at room temperature and safe for human consumption.

\section{Cost estimation}

Cost Analysis calculations of functional snack bars are shown in the Table 5. The calculation for cost estimation was done for $100 \mathrm{~g}$ of functional snack bar. The cost for the formulated functional snack bar (developed product) was Rs.9.57/100 g. These costs did not include transport, rent, local taxes, sale commission, etc. The cost of the developed FSB was lower as compared to the market available snack bars. This shows that as the incorporation level of oat and banana peel powder in place of amaranth grain decreased the cost of functional snack bar because there is no purchase cost of banana peel powder. The present investigated cost result is parallel to the finding of Virginia and Ajit (2014) in snack (biscuit, mathri and laddoo) from amaranth and watermelon seeds where the cost ranges between Rs.6.42-30.07 per 100 g. Therefore, we can say that our functional snack bar not only provides immense health benefits but also is low cost and can be consumed by all the sections of society.

\section{Conclusion}

It can be concluded from the study that the formulations containing amaranth grain $(60 \%)$, oats $(25 \%)$ and banana peel powder $(15 \%)$ was the most accepted on the basis of sensory evaluation performed by the judges. The samples were rated using the 9 point Hedonic scale. The proximate analysis of the formulated functional snack bar depicted that it fits into the category of snack bars as per the regulations given by FSSAI. The results revealed that the developed functional snack bar was rich in mineral content particularly in iron, phosphorus and calcium when compared to the control bar. The dietary fiber and $\beta$-glucan content in the bar were also present in significant amounts in the FSB as compared to the control. It was also observed that the snack bar had good inclination towards essential amino acid composition and total phenolic content. The TGA Analysis also showed that the active compound of functional snack bar can be stable up to more than $250{ }^{\circ} \mathrm{C}$. The FSB was microbiologically found to be safe for consumption even after a period of 60 days. The cost for the formulated functional snack bar (developed product) was 9.57Rs. per bar. This type of functional snack bar increases the market's revenue with boosts immunity, and is advantageous to people of all ages, especially children. Further research is needed for the shelf stability of functional snack bar and the best packaging material that may contribute to its stability.
Acknowledgements The work described has not been published before, it is not under consideration for publication elsewhere, its submission to JFST publication has been approved by all authors as well as the responsible authorities-tacitly or explicitly-at the institute where the work has been carried out, if accepted, it will not be published elsewhere in the same form, in English or in any other language, including electronically without the written consent of the copyright holder, and JFST will not be held legally responsible should there be any claims for compensation or dispute on authorship.

Authors contributions This work was designed by AS, AK, AKC. The experiments were carried out by AS and AK under the supervision of AKC. All authors contributed to the results and discussion. The first draft of the manuscript was prepared by AS and AK, and all authors contributed to the final version. All authors have read and agreed to the published version of the manuscript.

Funding None.

Availability of data and material The authors confirm that the data supporting the findings of this study are available within the article.

\section{Declarations}

Conflict of interest The authors declare that they have no conflict of interest.

Ethical approval This article does not contain any studies with human or animal subjects.

Consent for Publication All authors agree to publish.

\section{References}

AOAC (2019) Official Methods of Analysis of the Association of Official Analytical Chemists, seventeenth ed. Association of Official Analytical Chemists, Gaithersburg, MD

Bet DC, Oliveira SC, Colman DAT, Bisinella BZR, Beninca C, Lacerda GL, Ramos PA, Schnitzler E (2018) Aqueous extraction of organic amaranth starch and their by-products. J Therm Anal Calorim 138:2733-2749

Carvalho VS, Conti-Silva AC (2018) Cereal bars produced with banana peel flour: evaluation of acceptability and sensory profile. J Sci Food Agric 98(1):134-139

Chanda S, Dave R (2009) In vitro models for antioxidant activity evaluation and some medicinal plants possessing antioxidant properties: an overview. Afr J Microbiol Res 3(13):981-996

Correa AD, Jokl L, Carlsson R (1986) Amino acid composition of some Amaranthus sp. grain proteins and of its fractions. Arch Latinoam Nutr 36(3):466-476

Dahri NC, Ho LN, Tan TC, Mustafa A (2017) Composition, physicochemical, and physical properties of rolled oats snack bars formulated with green banana flour. World Appl Sci J 35(8):1361-1372

Darmasiw S, Betariana BB, Herawati O, Retnaningrum E (2018) Nutraceutical compounds production from guava seed waste fermentation. J Comput Theor Nanosci 24(6):4055-4057

Devi TB, Dash SK, Bal LM, Sahoo NR (2016) Physicochemical and microbiological characteristics of ginger paste (cv. Suprabha) during storage in different packaging and temperature conditions. Cogent Food Agric 2(1):1223261

Elgubbi HA, Miltan MA (2015) Colorimetric methods for determination of amino acids on thin layer and filter paper 
chromatography using a modified ninhydrin reagent. J Agric Sci Technol 5:190-193

Escudero NL, Albarracin GJ, Lucero Lopez RV, Giménez MS (2011) Antioxidant activity and phenolic content of flour and protein concentrate of Amaranthus cruentus seeds. J Food Biochem 35(4):1327-1341

Flander L, Marttila SM, Suortti T, Autio K (2007) Optimization of ingredients and baking process for improved wholemeal oat bread quality. LWT Food Sci Technol 40:860-870

Huang D, Ou B, Prior RL (2005) The chemistry behind antioxidant capacity assays. J Agric Food Chem 53:1841-1856

Joyce SA, Kamil A, Fleige L, Gahan CG (2019) The cholesterollowering effect of oats and oat beta glucan: modes of action and potential role of bile acids and the microbiome. Front Nutr 6:171

Kapadia SP, Pudakalkatti PS, Shivanaikar S (2015) Detection of antimicrobial activity of banana peel (Musa paradisiaca L.) on Porphyromonas gingivalis and Aggregatibacter actinomycetemcomitans: an in vitro study. Contemp Clin Dent 6(4):496

Kumari A, Chauhan AK (2021) Iron nanoparticles as a promising compound for food fortification in iron deficiency anemia: a review. J Food Sci Technol 1-17

Mogarkar PR, Morable DS (2018) Development and quality evaluation of puffed cereal bar. Indian $J$ Pure Appl Biosci 6(5):930-936

Momanyi D, Owino W, Makokha A (2020) Formulation, nutritional and sensory evaluation of baobab based ready-to-eat sorghum and cowpea blend snack bars. Sci Afr 7:e00215

Mridula D, Singh KK, Barnwal P (2011) Development of omega-3 rich energy bar with flaxseed. J Food Sci Technol 50(5):950-957

Munhoz CL, Guimarães RCA, Nozaki VT, Argandoña EJS, Hiane PA, Macedo MLR (2014) Preparation of a cereal bar containing bocaiuva: physical, nutritional, microbiological and sensory evaluation. Acta Scientiarum 36:553-560

Nath A, Dutta D, Kumar P, Singh JP (2015) Review on recent advances in value addition of jaggery based products. J Food Process Technol 7(3):2157-2171

Oguntoyinbo OO, Olumurewa JAV, Sade O (2021) Physico-chemical and sensory properties of cookies produced from composite flours of wheat and banana peel flours. J Food Stab 4(3):1-21
Pavlik V (2012) The revival of amaranth as a third-millennium food. Neuroendocrinol Lett 33(37):3

Pinto VRA, de Oliveira Freitas TB, de Souza Dantas MI, Della Lucia SM, Melo LF, Minim VPR, Bressan J (2017) Influence of package and health-related claims on perception and sensory acceptability of snack bars. Food Res Int 101:103-113

Písaříková B, Kráčmar S, Herzig I (2005) Amino acid contents and biological value of protein in various amaranth species. Czech $\mathrm{J}$ Anim Sci 50(4):169-174

Puraikalan Y (2018) Characterization of proximate, phytochemical and antioxidant analysis of banana (Musa sapientum) peels/skins and objective evaluation of ready to eat/cook product made with banana peels. Curr Res Nutr Food Sci 6(2):382-391

Ramírez-Jiménez AK, Gaytán-Martínez M, Morales-Sánchez E, Loarca-Piña G (2018) Functional properties and sensory value of snack bars added with common bean flour as a source of bioactive compounds. LWT-Food Sci Technol 89:674-680

Rasane P, Jha A, Sabikhi L, Kumar A, Unnikrishnan VS (2015) Nutritional advantages of oats and opportunities for its processing as value added foods-a review. J Food Sci Technol 52(2):662-675

Sahu AP, Paul BN (1998) The role of dietary whole sugar-jaggery in prevention of respiratory toxicity of air toxics and in lung cancer. Toxicol Lett 95:154

Sloan AE (2005) Top 10 global food trends. Food Tech 59:20-32

Tyagi P, Chauhan AK, Aparna (2020) Optimization and characterization of functional cookies with addition of Tinospora cordifolia as a source of bioactive phenolic antioxidants. LWT-Food Sci Technol 130:109639

Virginia P, Ajit P (2014) Development of nutritious snacks by incorporation of amaranth seeds, watermelon seeds and their flour. Indian J Community Health 26(Supp 1):93-101

World Health Organization (2004) Global strategy on diet. Physical Activity and Health, Geneva

Publisher's Note Springer Nature remains neutral with regard to jurisdictional claims in published maps and institutional affiliations. 